\title{
Sunflower meal for broilers of 22 to 42 days of age
}

\section{Lúcio Francelino Araújo ${ }^{1}$, Cristiane Soares da Silva Araújo ${ }^{2}$, Natália Barros Petroli ${ }^{1}$, Antonio Carlos de Laurentiz ${ }^{3}$, Ricardo de Albuquerque ${ }^{2}$, Messias Alves de Trindade Neto $^{2}$}

\footnotetext{
${ }^{1}$ Faculdade de Zootecnia e Engenharia de Alimentos - FZEA/USP, Pirassununga, SP - Brasil.

${ }^{2}$ Faculdade de Medicina Veterinária e Zootecnia - FMVZ/USP, Pirassununga, SP - Brasil.

${ }^{3}$ Faculdade de Zootecnia - UNESP, Ilha Solteira, SP - Brasil.
}

ABSTRACT - The objective of the present experiment was to evaluate the inclusion of sunflower meal in diets formulated on total or digestible amino acid basis fed to broilers of 22 to 42 days of age. Nine hundred and sixty birds were distributed in a completely randomized experimental design in a $2 \times 2$ factorial arrangement (two formulation criteria - digestible or total amino acids; two sunflower meal inclusion levels -0 or $15 \%$ ), with six replicates of 40 broilers each. Performance (weight gain, feed intake and feed conversion) and data from carcass characteristics (eviscerated carcass and commercial cuts) were evaluated. On day 42, six birds from each pen were sacrificed to determine digesta viscosity, and litter samples from each replicate pen were collected to determine litter moisture. The inclusion of $15 \%$ sunflower meal in broiler diets formulated on total amino acid basis worsens feed conversion ratio. Diets formulated on digestible amino acid basis are adequate when alternative feedstuffs, such as sunflower meal, are included. The use of sunflower meal in the diet does not influence carcass and cuts yields, but digesta viscosity increases when $15 \%$ of that feedstuff is included in the diet.

Key Words: carcass yield, digesta viscosity, litter moisture, performance

\section{Introduction}

Sunflower meal is a byproduct of sunflower seed oil extraction, and it is economically important due to its abundance and use as an alternative protein source in broiler feeds.

Literature studies present different chemical compositions of sunflower meal, and this may be attributed to different grain processing methods, as mentioned by Pinheiro et al. (2002). Despite being relatively rich in sulfur amino acids, sunflower meal is deficient in lysine in broiler diets. Silveira et al. (1967) and Rad \& Keshavarz (1976) demonstrated that the addition of lysine improves the performance of broilers fed diets containing sunflower meal as main protein source.

The high fiber content of sunflower meal also limits its use in poultry diets. According to Tavernari et al. (2008), the use of exogenous enzymes may be a solution for this problem, as these hydrolyze the non-starch polysaccharides, which then could be used by the birds, increasing, for instance, energy utilization.

Nutritionists have for years defined animal nutritional requirements based on the analysis of feedstuff composition, not taking into account their digestibility. According to Dale (1992), when formulating feeds based on their composition of total amino acids, rather than digestible amino acids, huge mistakes can be made, because the same relative values are attributed to both synthetic amino acids and those present in the feedstuffs, thereby underestimating the value of synthetic amino acids, which availability is of approximately $100 \%$, whereas those present in natural sources present lower availability.

In experiments with broilers, Uzu (1985), quoted by Jackson \& Dalibard (1995), evaluated the performance of broilers fed diets containing soybean meal, sunflower meal and canola meal, and formulated diets based on crude protein or ideal protein. When the diet was formulated on ideal protein basis, the replacement of soybean meal by sunflower meal did not compromise bird performance.

Therefore, the present study was developed to evaluated diets containing sunflower meal formulated on total or digestible amino acid basis fed to 22- to 42-day-old broilers.

\section{Material and Methods}

A total of 960 male broilers was allotted to a completely randomized experimental design with a $2 \times 2$ factorial arrangement, according to two formulation criteria (based on total amino acids or digestible amino acids) and two 
sunflower meal levels ( $0 \%$ or $15 \%$ ), totaling four treatments with six replicates of 40 broilers each. Sunflower meal was included at $15 \%$ in the diet, according to the recommendations of Furlan et al. (2001), and to supply the nutritional requirements estimated by Rostagno et al. (2005) (Tables 1 and 2).

Birds were housed in a $45 \mathrm{~m} \times 7 \mathrm{~m} \times 3.5 \mathrm{~m}$ experimental broiler house with clay-tile roof, concrete floor, and $0.5 \mathrm{~m}$ high walls covered with wire mesh, equipped with external curtains. House was divided in $1.5 \times 2.0$-m pens. The floor was covered with wood-shavings litter. Pressure drinkers and tray feeders were used during the first week, then gradually replaced by tube feeders and bell drinkers.

Table 1 - Chemical composition of sunflower meal

\begin{tabular}{lc}
\hline Composition & \\
\hline Metabolizable energy (kcal/kg)* & 1.810 \\
Crude protein (\%) & 31.40 \\
Calcium (\%) & 0.30 \\
Total phosphorus (\%) & 1.00 \\
Crude fiber (\%) & 23.00 \\
Methionine (\%) & 0.72 \\
Lysine (\%) & 1.22 \\
Methionine + cystine (\%) & 1.25 \\
Threonine (\%) & 1.19 \\
\hline
\end{tabular}

* Rostagno et al. (2005).
Birds were vaccinated against Marek's disease in the hatchery and against Newcastle disease and infectious bursal at 10 days of age. During the first days of age, brooding was made using focus-directed infrared lamps ( $250 \mathrm{~W}$ ). A lighting program of $24 \mathrm{~h}$ of light (both natural and artificial) was adopted, with lamps turned off during the day and turned on in the evening, during the entire rearing period. A maximum-minimum thermometer was used to record house temperature.

The experiment was carried out when birds were 22 to 42 days of age. Until 21 days of age, broilers were reared according to the conventional management of commercial farms, and fed a single diet. In the beginning of the experimental period, birds were weighed, selected, and distributed in the experimental treatments.

The following parameters were evaluated: feed intake, weight gain, feed conversion ratio, and carcass traits. When birds were 42 days of age, four birds with the average weight of each replicate were selected, fasted for six hours, and sacrificed for evaluation of their carcass, breast, leg (thighs plus drumstick), wings, and back yields.

At the end of the experiment, five sub-samples of approximately $200 \mathrm{~g}$ of the litter were collected at random from equally distant places in each pen to analyze litter moisture. The collected samples were placed in a plastic

Table 2 - Ingredients and calculated composition of the experimental diets

\begin{tabular}{|c|c|c|c|c|}
\hline \multirow[t]{3}{*}{ Ingredient (\%) } & \multicolumn{4}{|c|}{ Formulation criterion } \\
\hline & \multicolumn{2}{|c|}{ Total amino acids } & \multicolumn{2}{|c|}{ Digestible amino acids } \\
\hline & No sunflower meal & $15 \%$ sunflower meal & No sunflower meal & $15 \%$ sunflower mea \\
\hline Soybean meal & 30.20 & 15.64 & 30.29 & 15.78 \\
\hline Oil & 4.52 & 4.81 & 4.54 & 4.86 \\
\hline Dicalcium phosphate & 1.58 & 1.47 & 1.58 & 1.47 \\
\hline Salt & 0.42 & 0.43 & 0.42 & 0.43 \\
\hline Methionine & 0.27 & 0.28 & 0.24 & 0.24 \\
\hline Lysine & 0.09 & 0.41 & 0.07 & 0.37 \\
\hline Sunflower meal & 0.00 & 15.00 & 0.00 & 15.00 \\
\hline \multicolumn{5}{|l|}{ Calculated nutritional composition } \\
\hline Methionine (\%) & 0.58 & 0.59 & 0.54 & 0.56 \\
\hline Digestible methionine (\%) & 0.55 & 0.56 & 0.52 & 0.54 \\
\hline Methionine + cystine (\%) & 0.84 & 0.84 & 0.81 & 0.81 \\
\hline Digestible methionine + cystine (\%) & 0.92 & 0.92 & 0.89 & 0.89 \\
\hline Lysine (\%) & 1.12 & 1.12 & 1.11 & 1.09 \\
\hline Digestible lysine (\%) & 0.99 & 1.01 & 0.99 & 0.99 \\
\hline Crude fiber (\%) & 2.56 & 3.38 & 2.55 & 3.38 \\
\hline Sodium (\%) & 0.19 & 0.19 & 0.19 & 0.19 \\
\hline
\end{tabular}


recipient and homogenized, then one sample weighing approximately $250 \mathrm{~g}$ was removed and dried in a forcedventilation oven at $55^{\circ} \mathrm{C}$ for 72 hours. Immediately after drying, the sample was ground and dried at $105^{\circ} \mathrm{C}$ for 12 hours. Using the dry matter values obtained by air and oven drying, dry matter content was determined, and litter moisture percentage was calculated by difference.

Intestinal viscosity was determined by sacrificing six birds per replicate. The intestinal content of the segment corresponding to the beginning of the duodenal loop until Meckel's diverticulum was collected by manually squeezing this segment from the cranial to the caudal region. The collected digesta was placed in a beaker, immediately transferred to a test tube and centrifuged at 3,000 rpm for three minutes. With the aid of the micropipette, $0.50 \mathrm{~mL}$ of the supernatant were transferred to the ultra-thermostatic bath device for temperature stabilization, and then to a viscometer. Each sample was submitted to two determinations, and their average determined the viscosity value.

Data were submitted to analysis of variance using the procedures of SAS statistical package (Statistic Analysis System, 2001) and means were compared by Tukey’s test.

\section{Results and Discussion}

The use of digestible amino acids as feed formulation criterion significantly improved $(\mathrm{P}<0.05)$ bird performance during the experimental period (Tables 3 and 4 ). Despite the numerical decrease in feed intake, weight gain was higher in broilers fed diets formulated on digestible amino acid basis, which makes this formulation criterion economically interesting, as these birds gained more weight with the same feed intake than those fed the diet formulated on total amino acid basis.

Araujo et al. (2001) evaluated the performance of broilers fed diets based on the concepts of crude or ideal protein and observed that the diets formulated on ideal protein basis promoted higher weight gain, lower feed intake, and consequently, better feed conversion ratio.

In the present study, the inclusion of $15 \%$ sunflower meal in the diets reduced broiler weight gain $(\mathrm{P}<0.05)$ but did not affect feed intake ( $\mathrm{P}>0.05)$. Tavernari et al. (2008), using 0 and 20\% sunflower meal, concluded that, during the starter and entire experimental phases, feed intake was significantly lower when sunflower meal was used, which may be explained by the high crude fiber and vegetable oil dietary content; however, there was no significant effect on weight gain. Pinheiro et al. (2002) observed that the inclusion of $12 \%$ sunflower meal in broiler diet did not affect live performance, and that the best economic performance between three and 35 days was obtained when no sunflower meal was included in the diet, and from 36 to 42 days of age, with $4 \%$ sunflower meal dietary inclusion. On the other hand, Rama Rao et al. (2006) verified that sunflower meal can replace up to two thirds of soybean meal in broiler diets.

In the present study, there was significant effect of the interaction $(\mathrm{P}<0.05)$ between formulation criteria and sunflower meal dietary content on feed conversion ratio (Table 4).

The details of the interaction show that the use of $15 \%$ sunflower meal increased feed conversion ratio $(\mathrm{P}<0.05)$ when this feedstuff was used in the diets formulated on total

Table 3 - Performance of broilers fed diets containing sunflower meal or not and formulated on total or digestible amino acid basis during the grower phase (22 to 42 days)

\begin{tabular}{lcc}
\hline & Feed intake (g) & Weight gain (g) \\
\hline Formulation criterion & & $1.727 \mathrm{~B}$ \\
Total amino acids & $3.349 \mathrm{~A}$ & $1.744 \mathrm{~A}$ \\
Digestible amino acids & $3.295 \mathrm{~A}$ & \\
Sunflower meal levels (\%) & & $1.824 \mathrm{~A}$ \\
0 & $3.344 \mathrm{~A}$ & $1.646 \mathrm{~B}$ \\
15 & $3.305 \mathrm{~A}$ & $\mathrm{NS}$ \\
Formulation criterion $\times$ sunflower meal interaction & $\mathrm{NS}$ & 1.99 \\
$\mathrm{CV}(\%)$ & 3.74 & \\
\hline
\end{tabular}

Means followed by different letters in the same column, within each factor, are different $(\mathrm{P}<0.05)$ by Tukey test. NS $=$ not significant $(\mathrm{P}>0.05)$.

Table 4 - Details of the effects of the interaction (formulation criteria $\times$ sunflower meal level) on broiler feed conversion ratio

Formulation criterion

\begin{tabular}{lcc}
\cline { 2 - 3 } Sunflower meal level $(\%)$ & Total amino acids & Digestible amino acids \\
\hline 0 & $1.89 \mathrm{Aa}$ & $1.88 \mathrm{Aa}$ \\
15 & $2.00 \mathrm{Bb}$ & $1.94 \mathrm{Aa}$ \\
\hline \multicolumn{2}{l}{ Means followed by different capital letters in the same column and different small letters in the same row are different $(\mathrm{P}<0.05)$ by Tukey test. }
\end{tabular}


amino acid basis. On the other hand, when the diets were formulated on digestible amino acid basis, there was no difference $(\mathrm{P}>0.05)$ in the feed conversion ratio between the two levels of sunflower meal inclusion. Therefore, the worse feed conversion ratio result was obtained in broilers fed diets formulated on total amino acid basis and 15\% sunflower meal.

According to the study of Green (1987), broilers fed feeds formulated on digestible amino acid basis present better weight gain and feed conversion ratio.

Carcass and cuts' yields evaluated in the present experiment (Table 5) were not influenced $(\mathrm{P}>0.05)$ by the studied factors, demonstrating that sunflower meal can be fed to growing broilers.

Similar results were obtained by Oliveira et al. (2003) and Tavernari et al. (2008), who used 0 and $20 \%$ and 0,15 and $30 \%$ sunflower meal, respectively. Based on performance results, Furlan et al. (2001) verified that it is possible to replace up to $30 \%$ of soybean meal protein by sunflower meal protein, depending on the market price of sunflower meal at the time of utilization.

Rostagno et al. (1995) determined the true digestibility coefficients of amino acids in several feedstuffs, and analyzed the performance of broilers fed diets formulated on total or digestible amino acid basis. The results indicated that feeds formulated with alternative feedstuffs, such as sunflower meal, and based on total amino acid values promoted worse performance and breast yield. On the other hand, the diet with sunflower meal based on digestible amino acids resulted in similar performance, but lower cost, as compared with the diet containing corn and soybean meal.

In a previous study, Araújo (2001) evaluated the performance and carcass yield of broilers fed diets formulated on total or digestible amino acid basis during the periods of 22 to 42 days and 43 to 49 days of age and observed better performance, as well as carcass and breast yields in broilers fed diets formulated with digestible amino acids during the grower and finisher phases, respectively.

The inclusion of sunflower meal in the diet did not influence $(\mathrm{P}>0.05$ ) litter moisture (Table 6). Also, no effects of diet formulation criteria on digesta viscosity were detected, whereas sunflower meal inclusion increased it $(\mathrm{P}<0.05)$. The latter effect may be due to the high content of non-starch polysaccharides in sunflower meal, which may promote an increase in diet viscosity.

In the study of Brenes (1992), it was concluded that some anti-nutritional factors present in cereals may become soluble after ingestion, increasing digesta viscosity, which affects the nutritional value of cereals and also increases litter moisture.

Table 5 - Carcass and cuts yields of broilers fed diets with or without sunflower meal and formulated on total or digestible amino acid basis during the grower phase (22 to 42 days)

\begin{tabular}{|c|c|c|c|c|c|}
\hline & Carcass & Breast & Legs & Wings & Back \\
\hline \multicolumn{6}{|l|}{ Formulation criterion } \\
\hline Total amino acids & 68.21 & 40.72 & 27.81 & 10.82 & 20.74 \\
\hline Digestible amino acids & 68.20 & 42.35 & 27.06 & 10.68 & 19.90 \\
\hline \multicolumn{6}{|l|}{ Sunflower meal levels (\%) } \\
\hline 0 & 67.96 & 41.80 & 27.29 & 10.64 & 19.94 \\
\hline 15 & 68.45 & 41.26 & 24.27 & 10.87 & 20.70 \\
\hline Formulation criterion $\times$ sunflower meal interaction & NS & NS & NS & NS & NS \\
\hline CV (\%) & 1.87 & 3.74 & 3.72 & 5.86 & 5.17 \\
\hline
\end{tabular}

Means followed by different letters in the same column, within each factor, are different $(\mathrm{P}<0.05)$ by Tukey test.

NS = not significant $(\mathrm{P}>0.05)$

Table 6 - Litter dry matter content and digesta viscosity of broilers fed diets with or without sunflower meal and formulated on total or digestible amino acid basis during the grower phase (22 to 42 days)

\begin{tabular}{|c|c|c|}
\hline & Dry matter (\%) & Viscosity (cps) \\
\hline \multicolumn{3}{|l|}{ Formulation criterion } \\
\hline Total amino acids & 68.45 & 2.60 \\
\hline Digestible amino acids & 68.24 & 2.51 \\
\hline \multicolumn{3}{|l|}{ Sunflower meal levels (\%) } \\
\hline 0 & 67.93 & $2.46 \mathrm{a}$ \\
\hline 15 & 68.07 & $5.05 b$ \\
\hline Formulation criterion $\times$ sunflower meal interaction & NS & NS \\
\hline CV (\%) & 3.83 & 5.27 \\
\hline
\end{tabular}

Means followed by different letters in the same column, within each factor, are different $(\mathrm{P}<0.05)$ by Tukey test. NS $=$ not significant $(\mathrm{P}>0.05)$ 


\section{Conclusions}

The inclusion of 15\% sunflower meal in broiler diets formulated on total amino acid basis worsens feed conversion ratio. Diets formulated on digestible amino acid basis are adequate when alternative feedstuffs, such as sunflower meal, are included. The use of sunflower meal in the diet does not influence carcass or cuts' yields, but digesta viscosity increases when $15 \%$ of that feedstuff is included in the diet.

\section{Acknowledgements}

The authors thank FAPESP for funding this study (Process 03/02399-6).

\section{References}

ARAÚJO, L.F.; JUNQUEIRA, O.M.; ARAÚJO, C.S.S. et al. Proteína bruta e proteína ideal para frangos de corte no período de 1 a 21 dias. Revista Brasileira de Ciência Avícola, v.3, n.2, p.53-64, 2001.

ARAUJO, L.F. Estudo de diferentes critérios de formulação de rações, com base em aminoácidos totais e digestíveis para frangos de corte. 2001. 123f. Tese (Doutorado em Zootecnia) - Faculdade de Ciências Agrárias e Veterinárias/ Universidade Estadual Paulista, Jaboticabal.

BRENES, A. Effect of enzyme supplementation on the perfomance and digestive tract size of broiler chickens fed wheat and bardeybased diets. Poultry Science, v.72, p.1731-1739, 1992.

DALE, N. Formulación de dietas sobre la base de disponibilidad de aminoácidos. Avicultura Profesional, v.9, n.3, p.120-122, 1992.

FURLAN, A.C.; MANTOVANI, C.; MURAKAMI, A.E. et al. Utilização do farelo de girassol na alimentação de frangos de corte. Revista Brasileira de Zootecnia, v.30, n.1, p.158-164, 2001.

GREEN, S. Digestibilities of amino acids in foodstufs for poultry and pigs. AEC. Rhône Poulenc, Digestibility Republic, 8, 1987.

JACKSON, D.; DALIBARD, P. The mensurement and validation of the thechnique of using digestible amino acids for diet formulation in poultry and swine. In: SIMPÓSIO LATINOAMERICANO DE NUTRIÇÃO DE SUÍNOS E AVES, 1995, Campinas. Anais... Campinas: CBNA, 1995. p.47-72.

OLIVEIRA, M.C.; MARTINS, F.F.; ALMEIDA, C.V. et al. Efeito da inclusão de bagaço de girassol na ração sobre o desempenho e rendimento de carcaça de frangos de corte. Revista Portuguesa de Zootecnia, v.10, n.2, p.107-116, 2003.

PINHEIRO, J.W.; FONSECA, N.A.N.; SILVA, C.A. et al. Farelo de girassol na alimentação de frangos de corte em diferentes fases de desenvolvimento. Revista Brasileira de Zootecnia, v.31, n.3, p.1418-1425, 2002.

RAD, F.H.; KESHAVARZ, K. Evaluation of the nutritional value of sunflower meal and the possibility of substitution of sunflower meal for soybean meal in poultry diets. Poultry Science, v.55, n.5, p.1757-1764, 1976 .

RAMA RAO, S.V.; RAJU, M.V.L.N.; PANDA, A.K. et al. Sunflower seed meal as a substitute for soybean meal in commercial broiler chicken diets. British Poultry Science, v.47, p.592-598, 2006.

ROSTAGNO, H.S.; PUPA, J.M.R.; PACK, M. Diet formulation for broilers based on total versus digestible amino acid. Journal Applied Poultry Research, v.4, p.293-299, 1995

ROSTAGNO, H.S.; ALBINO, L.F.T.; DONZELE, J.L. et al. Tabelas brasileiras para suínos e aves: composição de alimentos e exigências nutricionais. 2.ed. Viçosa, MG: Universidade Federal de Viçosa, 2005. 186p.

SILVEIRA, J.; VELLOSO, L.; BECKER, M.N. et al. Farelo de girassol em substituição ao farelo de soja em rações de pintos. Boletim da Indústria Animal, v.24, n.8, p.129-138, 1967.

STATISTICAL ANALYSES SYSTEM - SAS. SAS-STAT User's guide. version 6.11, 6.ed. v.2. Cary: SAS Institute Inc., 2001. $824 p$.

TAVERNARI, F.C.; ALBINO, L.F.T.; MORATA, R.L. et al. Inclusion of sunflower meal, with or without enzyme supplementation, in broiler diets. Revista Brasileira de Ciência Avícola, v.10, n.4, p.233-238, 2008. 